\title{
HUBUNGAN BUDAYA ORGANISASI DENGAN KINERJA PERAWAT DALAM MEMBERIKAN PELAYANAN KEPERAWATAN DI RUMAH SAKIT MUHAMADIYAH TAHUN 2019
}

Tri Utami' , Romiko ${ }^{2}$, Sri Yulia ${ }^{3}$

STIKes Muhammadiyah Palembang

\section{Article Information}

Received: January 15t, 2020

Revised: June 26th, 2020

Available online: July, 2020

Keywords

Budaya Organisasi, Kinerja Perawat

\section{Correspondence}

Phone: (+62)82284491488

E-mail: t.utami1003@gmail.com

\section{ABSTRACT}

Latar Belakang: Budaya organisasi merupakan aspek penting dalam terciptanya sistem kinerja perawat yang baik. Budaya organisasi yang baik di ruang rawat inap akan mempengaruhi kinerja perawat menjadi lebih baik dan dapat menciptakan pelayanan yang bermutu.Tujuan Penelitian: Mengetahui hubungan budaya organisasi dengan kinerja perawat dalam memberikan pelayanan keperawatan di Rumah Sakit Muhammadiyah Palembang.Metode Penelitian: Penelitian ini bersifat kuantitatif dengan menggunakan pendekatan cross sectional dengan teknik purposive sampling dan jumlah sampel 50 responden. Alat pengumpulan data berupa kuesioner budaya organisasi dan kuesioner kinerja perawat dengan menggunakan uji chi square. Hasil: Terdapat 27 responden (54\%) perawat yang mempersepsikan budaya organisasi tinggi, 28 responden (56\%)yang memiliki kinerja baik dalam memberikan pelayanan keperawatan dan ada hubungan signifikan antara budaya organisasi dengan kinerja perawat dalam memberikan pelayanan keperawatan $(p$ value $=0,000)(\alpha$ 0,05). Simpulan: Budaya organisasi berhubungan dengan kinerja perawat dalam memberikan pelayanan keperawatan. Rumah sakit harus dapat meningkatkan kerjasama karyawan di rawat inap dalam menjalankan aktivitas kerja, sehingga kinerja yang diinginkan terwujud dalam menciptakan pelayanan keperawatan yang bermutu.

\section{PENDAHULUAN}

Budaya organisasi adalah filosofi dasar organisasi yang memuat,norma-norma dan nilai bersama yang menjadi karakteristik tentang bagaimana melakukan sesuatu dalam organisasi hal itu akan berkaitan dengan pegangan semua sumber daya manusia dalam organisasi dalam melaksanakan kinerja nya (Wibowo :2011)

Menurut Tewal (2017) Budaya organisasi merupakan berkaitan dengan nilai dan keyakinan yang ditumbuh kembangkan dalam organisasi untuk menuntun perilaku dan tindakan anggota organisasi tersebut.Budaya menjalankan fungsinya dalam Organisasi

Sedangkan Menurut Sembiring (2012) Budaya organisasi mengacu pada sistem makna bersama yang akan dianut oleh anggota -anggota yang membedakan organisasi lainya.

Budaya Organisasi memiliki fungsi : 
a.) Budaya membawa suatu rasa identitas bagi anggota-anggota organisasi.

b) Budaya mempermudah timbulnya komitmenpada sesuatu yang lebih luas dari pada kepentingan diri pribadi seseorang. dan c) Budaya meningkatan kemantapan sistem sosial akhirnya budaya berfungsi sebagai mekanisme pembuat makna dan kendali yang memandu dan membentuk sikap serta perilaku seseorang (Robbins dan Judge, (2013)

Kinerja Merupakan hasil kerja secara kualitas dan kuantitas yang dicapai oleh seseorang dalam melaksanakan fungsinya sesuai dengan tanggungjawab yang diberikan kepadanya (Pasolong: 2010).

Menurut Sinambela :(2012) kinerja merupakan pegawai dalam melakukan sesuatu keahlian tertentu kinerja sangatlah perlu sebab dengan kinerja akan diketahui seberapa jauh kemampuan pegawai dalam melaksanakan tugas yang dibebankan kepadanya.

Dari beberapa uraian diatas dapat disimpulkan bahwa kinerja merupakan hasil kerja seseorang dalam organisasi yang dicapai berdasarkan standar yang telah ditentukan untuk mencapai tujuan organisasi dalam periode tertentu .

Menurut Mathis dan Jackson (2012): a).Kemampuan Individual : Kemampuan individual mencakup pada bakatminat dan faktor kepribadian tingkat keterampilan merupakan bahan mentah yang dimilki oleh seseorang berupa pengetahuan, pemahaman,kemampuan,interpersonal,dan

kecakapan teknis.

b).Usaha yang diterapkan : ketika kinerja atau kehadiran dan motivasi dan tingkat dari usaha memiliki gambaran motivasi untuk menyelesaikan pekerjaan dengan baik dan seseorang akan memilki tingkat keterampilan untuk mengerjakan pekerjaan, tetapi tidak akan bekerja dengan baik jika hanya sedikit upaya.

c).Lingkungan Organisasional : Dalam lingkungan organisasional, organisasi menyediakan fasilitas bagi pegawai yang meliputi pelatihan dan pengembangan ,peralatan ,teknologi,dan manajemen.

Keberhasilan Organisasi tergantung pada sumber daya alam dirumah sakit yang dimiliki. Rumah sakit adalah suatu pelayanan medis yang dihimpun organisasi baik dari medis maupun non medis untuk menjalankan tata kelola rumah sakit. Rumah sakit MuhammadiyahPalembang merupakan salah satu rumah sakit swasta yang sudah akreditasi bintang lima atau paripurna dikota palembang provinsi sumatera selatan .oleh sebab itu, RSM Palembang ini berupaya untuk meningkatkan tujuan yang lebih maksimal

Sumber daya keperawatan merupakan sumber daya yang paling besar di RSM Palembang yaitu 37 orang (74\%).Sehingga dapat dikatakan baik jika peran perawat sangat besar dalam emebrikan pelayanan keperawatan yang dapat dilihat dari kinerja perawat tersebut.kinerja perawat yang baik dan professional akan dapat meningkatkan mutu pelayanan keperawatan oleh perawat secara keseluruhan

Hasil studi pendahuluan diruang rawat inap RSM Palembang yang dilakukan pada tanggal 20 Februari 2019 melalui wawancara dan observasi perawat pelaksana diperoleh data bahwa melakukan pekerjaan rutinitas, terlihat adanya perawat terlambat saat pergantian jadwal dinas sehingga operan dilakukan tanpa mempertimbangkan kelengkapan perawat

Setelah dilakukan wawancara kepada perawat tersebut, ada yang menyatakan kurang puas terhadap pekerjaan yang dilakukan nya .

\section{BAHAN DAN METODE}

Jenis penelitian yang digunakan pada penelitian ini yaitu penelitian bersifat kuantitatif dengan desain penelitian menggunakan pendekatan Cross Sectional untuk menentukan adanya hubungan antara variabel independen dan dependen Pada penelitian ini variabel in dependen adalah budaya organisasi dan variabel dependen adalah kinerja perawat dalam memberikan pelayanan keperawatan . Populasi merupakan sebagai keseluruhan objek yang diteliti (Sugiyono, 2010) Subjek dalam penelitian ini adalah seluruh perawat pelaksana yang bertugas di rawat inap Ahmad Dahlan, Ibnu Rusyid, dan Rasyid Thalib yang berjumlah 173. Karakteristik Responden Hasil Univariat disajikan dalam tabel distribusi frekuensi terdapat karakteristik jenis kelamin,variabel budaya organisasi dan kinerja perawat sedangkan SD,Nilai rata-rata,Min-Max. 
Tabel 1

Karakteristik responden berdasarkan umur dan masa kerja diinstalasi Rawat Inap RSMP Tahun 2019 $(\mathrm{n}=50)$

\begin{tabular}{|c|c|c|c|c|c|}
\hline Variabel & $\mathrm{N}$ & SD & $\begin{array}{l}\text { Mean } \\
\text { Median }\end{array}$ & $\begin{array}{l}\text { Min- } \\
\text { Max }\end{array}$ & $95 \% \mathrm{Cl}$ \\
\hline Usia & 50 & 4,084 & $\begin{array}{l}26,34^{-} \\
25,00 \\
\end{array}$ & $20-35$ & $\begin{array}{l}25,18- \\
27,50 \\
\end{array}$ \\
\hline $\begin{array}{l}\text { Masa } \\
\text { Kerja }\end{array}$ & 50 & 4,441 & $\begin{array}{l}8,54^{-} \\
8,00\end{array}$ & $1-21$ & $\begin{array}{l}7,28- \\
9,80\end{array}$ \\
\hline
\end{tabular}

Berdasarkan Tabel 5.1 diatas dapat dilihat bahwa rata- rata usia perawat adalah 26,3 tahun ,minimum 20 tahun dan maksimum 35 tahun dari hasil estimasi interval 95\% diyakini sebaran usia perawat adalah 25,18-27,50.Sedangkan rata-rata masa kerja perawat adalah 8,54 bulan,minimum 1 tahun dan maksimum 21 tahun dari hasil estimasi interval 95\% diyakini sebaran lama bekerja perawat adalah 7,28 9,8 bulan

Tabel 2

Distribusi Berdasarkan Jenis Kelamin dan Pendidikan Terakhir Dirumah Sakit Muahmmadiyah Palembang $(n=50)$

\begin{tabular}{llll}
\hline No & variabel & $f$ & $\%$ \\
\hline 1. & Jenis kelamin & & \\
\hline & a.Pria & 11 & 22,0 \\
\hline & b. Wanita & 39 & 78,0 \\
\hline \multicolumn{4}{l}{} \\
\hline \multicolumn{3}{l}{ Pendidikan terakhir } \\
\hline & a.DIII/ S.,Kep & 37 & 74 \\
\hline & b.S,Kep.,Ns & 13 & 26 \\
\hline
\end{tabular}

Berdasarkan Tabel 2 diatas, dapat dilihat bahwa sebagian besar perawat pelaksana di RSM Palembang memilki karakteristik responden berdasarkan Jenis Kelamin sebagian besar wanita (78\%) lalu kategori pendidikan terakhir sebagian besar DIII /S., Kep 37 (74\%) dan S., Kep.,Ns 13(26\%).

\section{Budaya Organisasi}

Hasil analisis univariat menunjukan bahwa persepsi perawat pelaksana tentang budaya organisasi RSM Palembang pada tabel sebagai berikut
Tabel 3

Distribusi Frekuensi budaya organisasi di intalasi Rawat inap RSM Palembang Tahun $2019(n=50)$

\begin{tabular}{llll}
\hline No & Variabel & $\mathrm{F}$ & $\%$ \\
\hline 1 & Budaya organisasi & & \\
\hline & a.Tinggi & 27 & 54 \\
\hline & b.Rendah & 23 & 46 \\
\hline & Total & 50 & 100 \\
\hline
\end{tabular}

Berdasarkan tabel 2 diatas, budaya organisasi di RSM Palembang pada kategori tinggi yaitu 54\%.Dan untuk kategori Rendah $46 \%$.

\section{Kinerja Perawat}

Hasil analisis univariat variabel dependen kinerja perawat pelaksana disajikan melalui distribusi frekuensi ( $f$ ) berdasarkan kategori baik dan kurang dapat dilihat pada tabel sebagai berikut :

Tabel 4 Distribusi Frekuensi Kinerja perawat pelaksana di instalasi Rawat Inap RSM Palembang tahun $2019(n=50)$

\begin{tabular}{lll}
\hline Variabel & $\mathrm{f}$ & $\%$ \\
\hline Kinerja perawat & & \\
\hline a.baik & 28 & 56 \\
\hline b.kurang baik & 22 & 44 \\
\hline Total & 50 & 100 \\
\hline \multicolumn{4}{c}{ Berdasarkan tabel } & 4 diatas dapat dilihat
\end{tabular}

bahwa sebagian besar perawat pelaksana di RSM Palembang berada pada kategori kinerja perawat bekinerja baik (56\%) . Hal ini menunjukan bahwa masih rendah nya kinerja perawat sehingga dapat mempengaruhi dalam memberikan pelayanan keperawatan dan mutu pelayanan di Rumah Sakit Muhammadiyah Palembang.

\section{ANALISIS BIVARIAT}

Hasil Analisis bivariat untuk mengetahui ada tidaknya hubungan antara budaya organisasi dengan kinerja perawat dengan menggunakan uji statistic dapat dijabarkan sebagai berikut : 


\section{Tabel 5}

Hubungan antara budaya organisasi dengan kinerja perawat dalam memberikan pelayanan keperawatan di instalasi Rawat inap RSM Palembang Tahun 2019 ( $n=50)$

\begin{tabular}{|c|c|c|c|c|}
\hline Variabel & Kiner & & Total & $\begin{array}{c}\mathrm{P} \\
\text { value }\end{array}$ \\
\hline $\begin{array}{l}\text { Budaya } \\
\text { Organisasi }\end{array}$ & Baik & $\begin{array}{l}\text { Kurang } \\
\text { baik }\end{array}$ & & \\
\hline $\begin{array}{l}\text { a.Tinggi } \\
\text { b.Rendah }\end{array}$ & $\begin{array}{l}26 \\
2\end{array}$ & $\begin{array}{l}2 \\
21\end{array}$ & $\begin{array}{l}96,3 \\
8,7\end{array}$ & 0,00 \\
\hline Jumlah & 28 & 23 & 100 & \\
\hline
\end{tabular}

Berdasarkan tabel 5 diatas dapat dilihat bahwa ada hubungan antara budaya organisasi dengan kinerja perawat pelaksana $(p<0,05)$.

\section{PEMBAHASAN}

\section{Karakteristik Responden}

Hasil penelitian Karakteristik individu dapat dikeahui bahwa umur rata-rata dari sebagian besar perawat adalah 26,3 tahun ,minimum 20 tahun dan maksimum 35 tahun hal ini berarti pada umur tersebut termasuk kategori umur dewasa muda .Jenis kelamin responden perempuan sebanyak 39 orang $(78,00)$ dan 11 orang $(22,0)$ yang berjenis kelamin lakilaki .hal ini berarti mayoritas responden berjenis kelamin perempuan.Pendidikan terakhir perawat sebagian besar perawat yang berpendidikan D3 Keperwatan /S.,Kep sebanyak 37 orang $(74,00)$ Dalam penelitian ini sebagian besar perawat pelaksana berpendidikan D3Keperawatan. Tingkat pendidikan dapat meningkatkan bila kemampuan perawat baik dari segi intelektual, teknikal dan interpersonal yang dibutuhkan dalam memberikan pelayanan keperawatan. Lama kerja dari sebagian rata-rata masa kerja perawat adalah 8,54 bulan,minimum 1 tahun dan maksimum 21 tahun dari hasil estimasi interval 95\% diyakini sebaran lama bekerja perawat adalah 7,28 9,8 bulan.

Lamanya waktu seseorang dalam menentukan pilihan pekerjaan yang cocok adalah 5 tahun. Lama bekerja perawat akan membuat pengalamannya lebih baik dan sudah dapat beradaptasi dengan budaya organisasi baik dilingkungan pekerjaannya sesuai dengan penelitian. (Rudianti,Handiyani,Sabri, 2013).

\section{Budaya Organisasi}

Budaya organisasi adalah filosofi dasar organisasi yang memuat, norma-norma dan nilai bersama yang menjadi karakteristik tentang bagaimana melakukan sesuatu dalam organisasi hal itu akan berkaitan dengan pegangan semua sumber daya manusia dalam organisasi dalam melaksanakan kinerja nya (Wibowo :2011)

Budaya Organisasi dalam memberikan Pelayanan Keperawatan penelitian inididapatkan data sebanyak 27 responden (54\%) mempersepsikan budaya organisasi tinggi dalam memberikan pelayanan keperawatan, dan 23 responden (46\%) budaya organisasi itu rendah .Dari data ini terlihat bahwa sebagian perawat mempersepsikan budaya organisasi tinggi yaitu (54\%)

Hal ini dapat disimpulkan bahwa budaya organisasi memiliki persepsi yang tinggi dan sebagian kecil rendah budaya organisasi dengan kinerja perawat dalam memberkan pelayanan keperawatan di Rumah Sakit Muhammadiyah Palembang Tahun 2019 dapat saling mempengaruhi jika memilki komponen yang lebih baik. Berdasarkan studi literatur dan hasil penelitan, peneliti berasumsi bahwa perawat yang tidak mempersepsikan budaya organisasi akan menimbulkan perubahan perilaku ke arah yang negatif seperti tidak percaya diri, kurang begairah dalam bekerja dan lain-lain. Sedangkan Perawat merasa sebaliknya, mereka akan merasa ikhlas apa yang dikerjakan dan bangga ketika mempersepsikan budaya organisasi yang maksimal .

\section{Kinerja Perawat}

Kinerja perawat merupakan hasil kerja secara kualitas dan kuantitas yang dicapai oleh seseorang dalam melaksanakan fungsinya sesuai dengan tanggung jawab yang diberikan kepadanya (Pasolong: 2010).

Berdasarkan tabel 5.6 dapat dilihat bahwa dari variabel dependen (Kinerja Perawat) sebagian besar perawat bekinerja baik perawat sebanyak 28 
responden (56\%) dan sebagian kecil bekinerja kurang baik sebanyak 22 Responnden (44\%).

Karakteristik responden dalam penelitian ini terdiri dari umur, jenis kelamin,pendidikan dan masa kerja dapat dijelaskan dalam penelitian Beberapa penelitian dan berdasarkan teori Meningkatnya kelelahan dapat memicu menurunnya kinerja. kelelahan yang muncul dapat disebabkan oleh adanya peningkatan tuntutan kerja yang menuntut perawat untuk bekerja secaara maksimal dan profesional.jika dilihat dari segi pendidikan, sebagian besar responden berpendidikan S1 Keperawatan dan dari masa kerja sebagian besar oleh responden dengan masa kerja antara 1 - 5 tahun sebesar 38 responden $(36,4 \%)$.

Banyak para ahli menyebutkan bahwa faktor yang mempengaruhi kinerja seperti menurut Gibson,ivanvech dan Donnely (2010) mengatakan bahwa faktor yang mempengaruhi kinerja ada tiga yaitu variabel individu ,variabel psikologis, ataupun variabel organisasional. Sedangkan Faktor yang mempengaruhi kinerja menurut Mathis dan Jackson (2012):

a. Kemampuan Individual

b. Usaha yang di Terapkan

c. Lingkungan Organisasional

Berdasarkan hasil analisis univariat dari 50 responden menunjukkan bahwa 28 responden (56\%) memiliki kinerja baik, dan 22 responden (44\%) memiliki kinerja kurang baik. Hasil penelitian lain juga menunjukkan bahwa perencanaan kepala ruangan sudah terencana dengan baik tetapi kinerja perawatnya masih kurang baik yaitu 10 responden (13.0\%), hal ini dapat dipengaruhi oleh karakteristik perawat di ruang rawat inap seperti pendidikan, masa kerja serta pengetahuan perawat.

Hal ini dapat disimpulkan bahwa dalam kinerja perawat dirumah sakit muhammadiyah responden memiliki kinerja baik sebanyak 28 (56\%) ,maka peneliti berasumsi bahwa kinerja perawat dalam memberikan pelayanan keperawatan merupakan suatu hal yang penting untuk membentuk perilaku perawat dalam memberikan pelayanan sehingga dapat menghilangkan rasa toleransi, dan percaya diri mereka.

\section{Analisa Bivariat}

\section{Hubungan Budaya organisasi dan kinerja perawat dalam memberikan pelayanan Keperawatan}

Berdasarkan uji yang dilakukan menggunakan chisquare menunjukkan bahwa $p$ value $=0,000<0,05$ dari 27 perawat yang memiliki kinerja baik, ada sebanyak 26 (96,3\%) perawat yang bekinerja baik dalam memberikan pelayanan keperawatan. Dari 21 perawat yang memiliki kinerja kurang baik, ada sebanyak $26(96,3 \%)$ perawat yang bekinerja baik dalam memberikan pelayanan keperawatan .

Pembentukan budaya organisasi dapat terjadi pada seleksi tim dalam organisasi untuk mensosialisasikan nilai didalam organisasi kepada perawat pelaksana dan akan bekerja secara maksimal dan memilki motivasi untuk bekarya dengan apa yang diharapkan organisasi Zees ,(2011).

Fungsi dari Budaya organisasi dapat memberikan identitas organisasi kepada pegawainya memudahkan komitmen yang kolektif serta dapat mempromosikan stabilitas kerja yang dirasakan positif dan mendukung dari konflik .

Hasil penelitian ini sejalan dalam penelitian Idrawati (2014) didapatkan bahwa 56\% perawat mempersepsikan bahwa organisasi itu lemah dan $78 \%$ perawat bekinerja baik. Selanjutnya penelitian sejalan dengan penelitian Andriani (2012) terdapat hubungan antara budaya organisasi dengan kinerja perawat.Pendapat ini juga sejalan dengan penelitian yang dilakukan hasil analisa bivariat menunjukkan hubungan yang signifikan antara budaya organisasi dengan kinerja perawat dalam memberikan pelayanan keperawatan dengan $p$ value $=0,05$.

Hal ini dapat disimpulkan bahwa terdapat hubungan yang signifikan antara budaya organisasi dengan kinerja perawat dalam memberikan pelayanan keperawatan di Rumah Sakit Muhammadiyah Palembang Tahun 2019 jika budaya organisasi tinggi maka kinerja perawat dalam memberikan pelayanan keperawatan memiliki kinerja yang baik .Berdasarkan studi literatur dan hasil penelitian, peneliti berasumsi bahwa semakin baik kinerja perawat dalam memberikan pelayanan keperawatan maka perawat akan menjadi semangat 
dan bergairah dalam bekerja Pada penelitian ini perawat lebih banyak yang bekinerja baik dalam memberikan pelayanan keperawatan yang ditandai dengan perilaku dari perawat yang baik yakni hampir semua perawat pernah mendengar mengenai budaya organisasi dalam suatu pekerjaan.

\section{KESIMPULAN}

Budaya organisasi perawat diruang rawat inap rumah sakit muhammadiyah palembang tahun 2019 didapatkan (54\%) yang mempersepsikan budaya organisasi itu tinggi Kemudian pada Kinerja perawat dalam memberikan pelayanan keperawatan dirumah sakit muhmmadiyah palembang diapat (56\%) memiliki kinerja baik dalam memberikan pelayanan keperawatan serta Ada hubungan antara budaya organisasi dengan kinerja perawat dalam memberikan pelayanan keperawatan dirumah sakit muhammadiyah Palembang tahun 2019 dengan nilai $p$ value $=$ sebesar $0,000(p$ value $\leq 0,05)$

\section{DAFTAR PUSTAKA}

Andriani, dkk. (2012). Hubungan Budaya Organisasi dan Karakteristik Perawat dengan Kinerja Perawat Pelaksana di Ruang Rawat Inap RSUD Dr. Achmad Mochtar Bukittinggi Tahun 2012. Tesis. Universitas Andalas Padang

Gibson,James L,John M Ivancevich dan James $H$. Jr.Donnely(2010).Organisasi dan managemen. Edisi Terjemahan. Jakarta.Erlangga.

Idrawati, Bahar (2014). Hubungan Budaya Organisasi dengan Kinerja Perawat Pelaksana di Ruang Rawat Inap Rumah Sakit Islam Ibnu Sina YarsPadang.Tesis,Andalas Padang

Mathis, Robert, L, and John H.Jackson. (2012). Manajemen Sumber Daya Manusia Jakarta .Salemba Empat

Pasolong,H. (2010) Pembangunan Sumber Daya Manusia Perspektif.Administrasi Publik. Jurnal Administrasi Negara STIA-LAN. Hal: 23-28.

Robbins,S. P.and T.A.Judge.(2013). Organizational Behavior . 15th Edition.Pearson Prentice.

Rusdianti Y., Haniyani, H., \& Sabri, L. (2013).Peningkatan kinerja perawat
Pelaksana melalui komunikasi organisasi di ruang rawat inap rumah sakit.Jurnal Keperawatan Indonesia 16(1), 25-32 Hall.New Jersey

Sinambela ,Lijan Poltak ,dkk.(2012) Kinerja pegawai teori pengukuran dan implikasi .Yogyakarta :Graha Ilmu.

Sembiring,(2012). Budaya dan kinerja organisasi.Fokus Media.Bandung

Sugiyono. (2010).Statistika untuk penelitian .Bandung :Alfabeta

Wibowo. 2011. Perilaku Dalam Organisasi. Edisi Ke-dua. PT RajaGrafindo Persada. Jakarta.

Zees ,Rini F(2011).Analisis Faktor Budaya Organisasi yang Berhubungan dengan Perilaku Caring Perawat Pelaksana di Ruang Rawat Inap RSUD Prof.Dr.H.Aloei Saboe Kota Gorontalo .Poltekes Gorontalo 